УДК 111.8

\title{
The Neo Human: a Breakthrough of Transcendence and Cultural Constraints
}

\author{
Viacheslav I. Kudashov* \\ Siberian Federal University \\ 79 Svobodny, Krasnoyarsk, 660041, Russia
}

Received 21.01.2015, received in revised form 21.02.2015, accepted 14.06.2015

\begin{abstract}
Aspiration of human to transcendence and the desire to expand the transcendental experience are considered in the context of prospects for new humanism, understanding of the problem of "neo human" and "post-humanism" consisting of various practices of "post-physicality". The ability of transcendence, to overcome the limited subjectivity and achieving integrity of "self" are seen as an important metaphysical property of the person. Some of the socio-cultural constraints in the ideology of anthropological conversion are highlighted: nepotism, femininity, national traditions. The author believes that today's request for transcendence expresses criticism of reality, deep dissatisfaction with the present, the reluctance to accept some limited modifications of the old and the search for the development of the new.
\end{abstract}

Keywords: transcendental, humanism, post-humanism, neo human, transcendence, cultural constraints, traditions.

DOI: $10.17516 / 1997-1370-2015-8-8-1642-1651$.

Research area: philosophy.

\section{Expanding the Boundaries of a Personality}

Spiritual history of the last decades has revealed a movement of thought towards the individual metaphysics in the context of the freedom as a responsibility. The ontological meaning of this movement lies in the fact that the subject of self-consciousness is a carrier of freedom in a situation of global responsibility. This trend shows the search for an organic connection of man with a universal rational principle, that is the release of a specific person outside the space-time and causal boundaries. The "I" becomes "a point of responsibility" in the real and virtual worlds, the assemblage point of the self-conscious "I" that is not so much separated from being, as it is woven into its fabric. You can find yourself only in the world through opening up and trusting yourself to the infinitely open dynamism of its creative change.

The problem there is that the boundaries of freedom and responsibility, as well as the boundaries of identity, lose the classical clarity of modern times. The postmodern project of disintegration of personality only sharpens the fact of contradiction of "I" to any its definition because "I" appears as protagonist, elusive to any characteristic and appears as a transcendental

C) Siberian Federal University. All rights reserved

* Corresponding author E-mail address: vkudashov@mail.ru 
subject. Therefore, self analysis is possible on the way out of yourself in different worlds and their projections, just as the responsibility for your own way and the ability to find unique meanings.

But how can a breakthrough in the transcendentaland the expansion of transcendental experience be possible? Finding answers to these questions may be associated with the prospects of new humanism, with the comprehension of the problem of "neo human". Despite the ambiguity of interpretations of this concept, the general idea is a universal philosophical intention of anthropological research and its creative boundaries to overcome. The European tradition of philosophizing uses Latin prefixes "post" and "trans" to understand the "new man", Russian religious philosophy talks about "Godmanhood", criticizing Nietzsche for his idea of the "superman", modern scholars hold prospects for the evolution of the concept of humanitarian "neo human". We also think it is more appropriate, since it implies not so much a radical renunciation of the "old" man as biosocial overcoming habits and inclinations, unworthy of high humanistic ideals and values.

\section{"Neo Human" and "Post-Humanism"}

Appeal to the discourse of "neo human" was the subject of attracting more gaze of researchers and thinkers in various fields where the transition to a new person is evaluated as a movement to a higher level of organization of life. The prospects of finding new transcendence are possible in the context of an increasingly distinct trend of "posthumanism", which includes various practices of "post-corporeality" (Evolution and the Future Anthropology, Ethics, Religion). Already, many of the achievements of biotechnology, genetic engineering, transplantation reached a level where it became quite possible to change not only the appearance, internal organs, but also the gender, so that the body can turn into a sort of natural shell, which can be not only decorated, but also changed.

This results in a new ethical problem of loss of identity and relevance in the relations between people of different generations who are losing a common conception of pregnancy and birth. But the severity of the changes taking place with a man is not about changes in some spiritual and ethical dimensions, not in the opposition of outdated values to new values, which is quite common in history, but the formation of new dimensions of human existence.

Therefore, some philosophers have expressed their concern that after the advent of the post-human all the old system of measurement of human life can become meaningless and unnecessary: the conscience, honor, duty, freedom, humanity, compassion, goodness. For example, the Russian philosopher Vladimir Kutyrev believes that even if the Nietzschean superman was a peculiar form of confirmation of the existence of God, if the representative of the society of militant atheism was a man who forgot about God, the post-human by nature is incapable of thinking about God, goodness, love, truth, beauty, and all the things that go beyond the visible, material bodily world. But "human" means "belonging to humanity, possessing qualities or attributes of a person belonging to or characteristic of the human race" (Kutyrev, 1994, 139).

Representatives of the trans-humanist movement are just going to change many of these qualities and traits. They believe that many human traits are uncomfortable or harmful, and the majority wants to develop positive traits of human nature, such as compassion, and get rid of the negative. In their view, there is no intrinsic value in being human, just as there is no intrinsic value in being a stone, a frog or a post-human, and the value lies in "who we are as individuals", and "what we do about our life". 
Despite the fact that on the way of progress we have drifted a long way away from the animal, the total separation has not happened. "But sooner or later it will happen", says A.P. Nikonov. However, it is those who are so anxious and angrily asserting that man is not an animal, "for some reason show the strongest protest against the complete separation of the mind from a biological medium, which promises the development of the technology. Any word on the genetic improvement of man and his possibility of becoming a cyborg, on transferring the mind on another media are perceived by intellectuals and romantics with anger! They are denying our animal essence and at the same time they are completely attached to it!" (Nikonov, 2004, 126).

Post-humanism, not being a cult or a religion, in some situations, may perform some functions that people have traditionally had for religion because it offers its understanding of the meaning and the purpose of existence, and the idea that people can achieve more than they have achieved for today. Although the religious idea of the soul does not fit well with the rationalist philosophy, many post-humanitarians are interested in the issues related to personal identity and the nature of consciousness. It is interesting to note that even Dalai Lama does not exclude the possibility of reincarnation in the computer reality (Strategicheskoe obshchestvennoe dvizhenie «Rossiia 2045». Transgumanizm).

Unlike the majority of believers, posthumanitarians are trying to implement their dreams in the world, relying not on supernatural powers, but on rational thinking and relentless scientific, technological, economic and personal development. To date there is no reliable evidence for the existence of supernatural forces or unexplained spiritual phenomena, so posthumanitarians prefer to rely on best practices, particularly scientific ones, in order to study nature and implementation of changes in the nature. At the same time they realize that the scientific method has its drawbacks and are not infallible, but they believe that many prejudices can be overcome with the help of humanistic education, training, critical thinking, and communication with representatives of different cultures. Post-humanitarians are ready to learn and understand their mistakes, so that later they could appropriately adjust their attitudes and perceptions.

It is worth noting that post-humanism is not some immutable and unambiguous set of dogmas. Rather, it is an evolving world, or even a family of evolving worldviews as post-humanitarians often disagree with each other on many issues. In our view, "the philosophy of post-humanism" is still in its infancy, and needs to continue to evolve in the light of new experiences and new opportunities, contributing to understanding of the "eternal" philosophical problems.

\section{The Idea of "Transcendental"}

Among those, of course, stands the idea of "transcendental", which belongs to the circle of the fundamental meaning of human existence, expressing aspiration, which is inherent for the consciousness. And the religious sense of the transcendent is only one form of existence of this idea. The term "transcendent" (Latin "going beyond") underlies a set of meanings that, despite the diversity of their ways of understanding (philosophical thought, religious belief, aesthetic experience, intuition, mystical experiences) express aspects of the limitations of our world perception, experience, thinking, and the presence of the beyond of being outside the boundaries of this world.

Aspiration of the consciousness to its limits shows the immensity of human - his (her) unwillingness to be satisfied with "a measure of" existential destiny and the desire to learn as much as possible about the existential sphere, 
to establish itself there. Man is a creature that pushes the limits, has the intention to expand into existence, and "transcendental" is a constantly elusive and extending boundary of this aspiration of an individual's self. Hence the ideas of "the beyond" have a high value status, because they are a justification for limitations that support the experience and world view.

The first form of this idea is transcendence as a hyperreality of the universal consciousness. There was this idea through the metaphorical transfer of refined qualities of the self in a world apart, so the emergence of the idea of "transcendental" is associated with the formation of the sovereignty of the individual consciousness. This idea arises as a consequence of radical self-distinguishing of the consciousness emerging from the outside world and the desire to understand the reason for such a radical difference. All that determines the stipulation that I "am not from this world» but from another world - more valuable, higher, ideal: Brahman, Dao, the Logos, God's kingdom. In real studies on "axial time" all that looked a little bit simpler: the world of sight, materiality and suffering confronts the world of truth and perfect bliss. The idea of "transcendental" in its first form is a becoming ontology of the "childish", narcissistic I. Higher reality in Brahmanism, Buddhism, Daoism is a reality of hyper-consciousness, "the I projection on the universe", which substantiates profane, everyday reality.

Further the development of the idea of transcendence happening in the context of salvation religions (Judaism, Christianity, Islam), coinciding with the idea of a single "God" in contrast to the mythological and polytheistic beliefs, which do not assume the dualization of the world in terms of "natural" and "supernatural". Two approaches to the comprehension of the meaning of the transcendental have developed in theology: positive (cataphatic) and negative (apophatic). The first way is to comprehend the transcendent ascent on a scale of abstraction and scale of values - the values of the ordinary, the outside world to a high degree of commonality of values (Light, Life, Blessing, Love, Beauty, Wisdom and Omnipotence). The second consists of the successive denial about God 's all properties, all the qualities observed and imaginable in the world, since the God transcends any possible comprehension.

The development of the idea of the transcendental in the context of religion has made it the subject of intense intellectual work, which explains its gradual secularization and transformation into an object of philosophical reflection. The philosophical meanings of the transcendental are clearly presented in Kant's works, in fact, he was concerned with finding the boundaries and limits of knowledge, perception and thought. "Transcendence" as a regulative idea shows how Kant believed, not only in a possible reality, foreign to our own reality and presented through the "phenomena", but also acting abroad, embracing and expressing all qualities of the human world (transcendental). Kant's "transcendental" simultaneously acts as the highest idea of transcendence - the limit base, marking the highest reality that constitutes all possible meanings of the world. It is, according to Kant, "an entity that initially contains a sufficient basis for any possible action and the concept of which is easy to determine with only one feature of the all-inclusive perfection" (Kant, 1994, 357). Thus, Kant's transcendental is the idea of pure reason, which has a regulatory destination for knowledge and practical behavior.

L. Feuerbach expressed an anthropological understanding of transcendence as an illusion rooted in human nature, as a consequence of the desire to go beyond the boundaries of our existence. Transcendence, according to Feuerbach, occurs as a nature of man projected 
outward and raised to the power of infinity (love, intelligence, will) (Feuerbach). A similar version of the anthropological interpretation of the transcendental was proposed G. Zimmel, who considered this idea to be the most important in the intellectual development of mankind: the ability of reflection, attention, abstraction (Zimmel). It is an imaginary ideal point of tightening of our intrinsic forces or substantializing our qualities: love, excellence, goal-setting.

The psychological explanation of the meaning of the transcendent is represented in the psychoanalytic tradition. Freud's transcendence is a "counter effect" to feelings of dependence and helplessness that people feel from a collision with external and internal forces which are immensely superior to them. The idea of "God" is formed by man unconsciously, from the materials of his (her) life experiences in childhood, creating an image of omnipotent, fair and loving creatures. Jung speaks of transcendence as of a metaphorical designation of the species, a source of vitality and creativity, lying in the collective unconscious. It is rooted in all possible ideas and doctrines to which access is limited due to the artificial barriers erected by the formalistic intelligence.

It seems that many philosophers have been close to this metaphor, speaking of the "world will" (Schopenhauer), "the unconscious world" (Hartmann), "Life" (Dilthey, Zimmel, Bergson), "world openness" (Scheler). Experiencing this understanding of transcendence in altered states of consciousness determines the beginning of the vitality of the form, which is blind to personal goals, values, and exists by itself. The world of "I" is an intelligible world of the consciousness - existential vitality antagonist, although its stability eats "energy" of the same vitality. Therefore transcendence is in every cell of our body as an almighty beginning, which spontaneously and through many mediations appears to us in a rich range of values of philosophy, religion, psychology, and art: "God", "cosmic consciousness", "the boundaries of perception and thought", "regulative ideal", "intentional limit", "the incomprehensible".

\section{An Individual's Ability to Achieve Transcendence}

An important metaphysical property of human is his potential ability to transcendence, to overcome his limited subjectivity and to achieve the integrity of the "I". According to Y. Petrov, "a person goes through the transcendence of subjectivity. Man as a person realizes himself only in this way ... Transcendence is the depth of the world of existence, and in it man finds his freedom by fighting foreign determination. Everything that exceeds human transcendence, is perceived as not impersonal, but in very different personal forms. A man in such a world does not lose himself, does not become socialized but remains himself - the self that says about the authenticity of the person. In the world of transcendence a personality acts as a holistic structure" (Petrov, 2002, 685).

Thebeareroffreedomandspiritualexperience of consciousness is not just a person, but a person, the spatial and temporal boundaries of whom are defined and set by responsibility of the boundaries of freedom, i.e., sanity. The psychosomatic basis of personality is still predominantly a man as a representative of a particular species. Therefore, an important aspect of individual freedom lies in the conditions of human existence as a biological species, preserving his (her) psychosomatic integrity, from living conditions to high-tech medical care. The formation and development of the human personality provides a culture as a non-genetic system of generation, preservation and transmission of social experience. The development of specific cultures: national, ethnic, age, professional, etc. provides socialization and individualization of a personality. 
At the same time, from a rational point of view, there are no absolute moral or ethical reasons why you cannot interfere with nature and improve it. After all, the whole humanity, all actions and works of man are also part of the biosphere, and human intervention is a normal life of the biosphere. Using not invented, but quite natural patterns, you can destroy diseases, improve the efficiency of agriculture to feed a growing world population or launch communication satellites into an orbit to provide our home with news and entertainment.

Of course, in many cases, there are compelling practical arguments in favor of relying on natural processes. For example, some argue that human cloning is not artificial because human clones are, in fact, only identical twins. When we discuss whether to clone humans, it is necessary to compare the various desirable consequences and undesirable ones, then try to assess the likelihood of these effects. This method of discussion is much more complicated than just the rejection of cloning as an unnatural, but it is much more likely to lead to the right decision.

But does the idea of artificial enhancements of a person today make any sense or is it a phenomenon of social consciousness of the European utopianism of the nineteenth century, a painful expression of progressivist aspirations to infinity? Although this idea was most vividly and rationally expressed primarily in Europe, in our opinion, it is still common to all mankind. This "common humanity" does not mean "all inherence for all", but inherence to certain categories of people. The metaphysical aspiration, generating the idea of improving human nature, relies on the activist, strong-willed character. This hatred of dependence, submission, play on someone else's rules, despair before nothingness that are born out of longing for freedom, dreams of rich joys, adventures and trials of life, from the agonizing wait at least some novelty, thirsty existence. Only an intense degree of emotions inherent in certain categories of people is able to maintain a high intensity of these passions.

A weakened, exhausted option lies in the idea of patience, humility, and voluntary-soothing slavery - the spiritual foundation of both religion and everydayness of pragmatism so-called "conventional wisdom" and the philosophy of "natural attitude" of mass consciousness - "Let the cobbler stick to his last", "you cannon chop wood with a penknife", "do not spit into the wind", and more. We agree that from the point of view of the majority of species, the adherents of the ideas of "anthropological revolution", "neo human", such as supporters of the movement "Russia-2045" may not look appropriate in terms of the views shared by the majority (Strategicheskoe obshchestvennoe dvizhenie «Rossiia 2045 ». Ideologiia). Metaphysical rebels, calling into question the immutability of the forms of being kind, in terms of the majority have a sick reflection, pride, because they want to achieve freedom and immortality, not only metaphorically, in the mind, the spirit, but in the real, sensory-corporeal world.

The motivation of anthropological transformationislikely tobedeeplyindividualistic; it is always a revolt against its inheritance. But what for? For an indigenous fun to create and transform, to become the new work is the scale of the human world to be by itself, not a unit, a part and whole, and always be different. This excessive force manifests itself in spirituality, which sets new goals for itself. However, any even the highest spirituality is radically limited by the conditions of conservation of its body and the bodies of its relatives.

\section{Socio-Cultural Constraints}

\section{for Anthropological Transformation}

We need to recognize that many women have been and will be healthy stronghold of 
conservative forces, the eternal biological order, representing the evolution itself, a reproduction of the living. They are, like natural people carriers, perfect means of biological reproduction, will naturally hate the idea of intervention in nature, which they represent. The history of civilization shows the benefit of stable archetypes, which are fixed and will force the most significant part of the race, the nation, the people and will certainly contain a spiritual core of the baton, and universal moral principles, i.e. species wisdom.

Nepotism is also a universal human property, and the family is the most fundamental and conservative human institution, as well as a major source of religious and political rhetoric. All cultures are organized around the regulation of reproduction, and any reproduction is based on the preference of some sexual partners to others and children of their own - the children of others. Therefore, radical attempts to rework the human race are an offense against the family institution, and they will fail, or will be postponed for an uncertain future.

Any idea of the universal equality goes in conflict with family preferences and values, which are deeply related to the differences between native and non-native. Even Christianity, which calls to love other people's children as their own, could not resist, just making a vow of marriage as the exclusive loyalty to a religious sacrament, similar to the main institutions of tribal societies.

Traditions for a long historical time have been not only a way of transferring, but verification of the vital information, filtering it from all accidental, superficial, momentary or harmful. Traditions, coming from the innermost depths of the historical national identity, are the fundamental capital of people, who successfully master the modern stage of scientific and technological progress. Ethical standards, which have been laid down therein, are intended to ensure the survival under difficult conditions, to resist the blurry foundation of national selfesteem of influences and trends.

National traditions are particularly relevant in the era of accelerating scientific and technological progress and the pace of life, retaining the original humanistic roots, the real role and value of which is only now beginning to be realized in terms of the anthropological crisis. Traditions are a mechanism for accumulating and transforming, polished by centuries of experience of people, who have been supporting it. Most national traditions are just carries at their core of the idea of harmony with nature and harmonious, even calculated long-term effects, the relationship of people to each other within a social community.

Therefore, a large part of humanity is unlikely to support the project of radical change in human nature, recoiling in fear or religious traditionalist rejection. Who will be willing to experiment, many of the consequences of which will be grim or awful at first? It may be some intellectuals, to the greatest extent cut off from family and traditionalist values, idealists, who decided to "subdue the matter". Will these possible experiments be severely banned, and their proponents persecuted and expelled? Will it happen sooner, later or spread over a century? Will it be held in a terrible conflict or will go peacefully? Now we can only guess. But something that has already emerged will not disappear and will find other forms of its development.

According to G.L. Tulchinkii, "search for a new transcendence is inevitable for human existence. Inability to experience transcendence closes (at least!) The prospects for the development of knowledge and experience" (Tulchinskii, 2013, 62). To expand human understanding of his life, we need to recognize the existence of something unknown, transcendent communion which opens the way for the expansion of knowledge and experience, opening a new harmony and integrity of the new world. Man is a finite being, doomed 
to grasp the infinite world only "in some sense", with some limitations in space and time, after all, is a product of the very meaning of the final system, trying to understand the infinite.

Man cannot live in a disordered world, paralyzing its lack of guidance and the constant unpredictability. As a finite entity in infinity, human tends to establish a certain structure, order, stability, law in this infinity. Hence, the attempt to break into the transcendental, in other than a trans- and post-real, that sets and regulates this reality. The reality appears only as a manifestation of something more real, real truth.

Postmodernism criticizing the classical definition, with all its ambiguities, quite firmly and convincingly pointed to the failure of cultureas well as the self-sufficiency of art. Therefore, in order to identify all cultural limitations of the human evolution the postmodern "de-culturing" of the modern culture has a very significant impact, in which the culture itself becomes an object of the game of manipulation. Culture and creativity, put on an indestructible pedestal, find no reason in themselves, because the meaning is always given by a context.

Therefore, the so-called "dehumanization" of the modern culture and civilization, which is so fearful for other orthodox humanists, can be very fruitful. Modern body practices in science, medicine, and arts, a game with the body in everyday experience reveals the irrelevance of the given anthropomorphism. We can say that the modern "dehumanization" reveals the importance of true humanity, it allows "to see a forest in the trees" and a reliable path in it.

\section{Modern Request \\ For Transcendence}

To reveal the meaning of life we need to go into the broader context that gives meaning to life; to understand the meaning of existence is necessary to gain something more than a finite existence. And the person in contrast to animal is capable of such a transition of transcending into another. This experience of transcendence reveals a path to mastering the cause-and-effect relationship, to overcome our animal essence, and to master the nature. "The issue of our time is the question of the implementation of the craving for transcendence, the search for a new transcendence" (Tulchinskii, 2013, 60). In today's request for transcendence is expressed a critique of reality, and the search and development of new. It shows a deep dissatisfaction with the present and the reluctance to be limited by combinations and modifications of the old bored remakes of "songs about the main thing".

Now mankind has come to a verge, where it needs to cross it in order to change itself, or if did not comprehend itself, it will disappear. This line is sometimes even called a new round of evolution. What is the transition to a new quality of life? It must be in the liberation of the individual, in the approach to the ultimate goal of evolution the fulfillment of individual entities, return to a holistic existence. Inattention to this process, the habit of acting in the old way, insensitive to changes can lead to a disastrous crisis in the era of change. Those are not changes that organize a separate restless mind, but those changes through which a pattern of finding a way in the world can be revealed.

Mind generally compensates for disruptive factor of individual freedoms, restoring the individual universal meaning. Prospects of cosmic evolution elevate the individual consciousness of racial, ethnic and religious barriers, bringing it to a universalist perspective of the "new humanity". However, there is no guarantee that such a prospect and opportunity will be realized. A.P. Nazaretian believes that "the mind is built on a "natural" substrate, while reaching a grand freedom outside the safe biological limits, yet experiencing 
limitations inherent to need-affective programs. It cannot break away from the functional needs and emotions, it regularly needs acute feelings, and thus it is in constant turmoil and conflicts" (Nazaretian, 2013, 387). Therefore, "the decisive prerequisite for a strategic change of its semantic coordinates can be a further progress towards denaturalization of the media of intelligence with symbiosis of its forms" (Nazaretian, 2013, 388).

Of course, not all philosophers, and even science fiction writers solved for themselves the question of the inevitability of a radical transformation of the human in all its physical and spiritual dimensions. In the near future, humanity is unlikely massively to go the way of global anthropomorphosis - basic instincts including the instinct of preservation of the species put on serious limitations and hold it.
Probably, the irrational fear of humanoid robots, or their biological counterparts is associated with this basic instinct. But it must be remembered that every species has its own historical period determined by evolution.

People in this respect have a distinct advantage: the mind allows them to not only adapt to the environment, but also to alter it to suit their own needs, and will soon allow to fundamentally change the very nature of man. Is there a real need for that? Perhaps, there is no urgent need for humanity in its present state yet. But, most of all, as many fiction writers and philosophers are predicting, such a change is coming, when, in spite of the significant danger of transformation, too late to be asking about the desire to give up the present human form, because "human will be saved only by rejecting Human".

\section{References}

1. Clark, Andy. Natural-Born Cyborgs: Minds, Technologies, and the Future of Human Intelligence. New York: Oxford University Press, 2003.

2. Evolution and the Future Anthropology, Ethics, Religion. Frankfurt am Main, Berlin, Bern, Bruxelles, New York, Oxford, Wien, 2013. 188 p.

3. Strategicheskoe obshchestvennoe dvizhenie «Rossiia 2045». Ideologiia [Strategic Social Movement “Russia 2045”. Ideology]. (Electronic resource) Available at http://2045.ru/ideology (May 1, 2015)

4. Strategicheskoe obshchestvennoe dvizhenie «Rossiia 2045». Transgumanizm [Strategic Social Movement "Russia 2045". Transhumanism]. (Electronic resource) Available at http://2045.ru/ transhumanism (May 1, 2015)

5. Joy, Bill. Why the Future Doesn't Need Us // Wired, Vol. 8, No. 4 (April), 2000.

6. Krasikov, Vladimir I. Philosophizing in Russia: Dynamics in the Socio-Cultural Context// Journal of Siberian Federal University. Humanities \& Social Sciences 1 (2015 8) 64-76.

7. Moravec, Hans. Mind Children: the Future of Robot and Human Intelligence. Cambridge: Harvard University Press, 1990.

8. Zimmel, G. Izbrannoe. T. 1. Filosofiia kul'tury [Selected works T. 1. Philosophy of Culture]. M .: Iurist, 1996. $671 \mathrm{p}$.

9. Kant, I. Kritika chistogo razuma [Critique of Pure Reason]. M., 1994. 426 c.

10. Kutyrev, V.A. Estestvennoe i iskusstvennoe: bor'ba mirov [Natural and artificial: war of the worlds]. Nizhny Novgorod, 1994. 199 p.

11. Nazaretian, A.P. Nelineinoe budushchee. Megaistoricheskie, sinergeticheskie i kul'turnopsikhologicheskie predposylki global'nogo prognozirovaniia [Nonlinear future. Megaistoricheskie, synergies, cultural and psychological background of global forecasting]. M .: MBA, 2013. 440 p. 
12. Nikonov, A.P. Apgreid obez'iany. Bol'shaia istoriia malen'koi singuliarnosti [Upgrading monkey. Big story of a little singularity]. M., 2004. 352 p.

13. Petrov, V. Filosofiia cheloveka [The philosophy of human]. Tomsk: Publishing house of the YTL, 2002. $1004 \mathrm{p}$.

14. Tulchinskii, G.L. Sovremennost': immanentnost' i poiski transtsendentsii // Filosofskie nauki [Modernity: the immanence and transcendence searches // Philosophical Sciences]. 2013. № 5. Pp. 54-65.

15. Feuerbach, L. Izbrannie filosofskie proizvedeniia [Selected works on philosophy]. 2 V. Moscow: Politizdat, 1955.

\title{
Неочеловек: порыв в трансцендентное и культурные ограничения
}

\section{В.И. Кудашов}

Сибирский федеральный университет Россия, 660041, Красноярск, пр. Свободный, 79

\begin{abstract}
Устремленность человека в трансиендентное $u$ стремление $\kappa$ расширению трансиендентального опыта рассмотрены в контексте перспектив нового гуманизма, осмысления проблемы «неочеловека» $u$ «постгуманизма», включающей различные практики «пост-телесности». Способность к трансиендированию, преодолению своей ограниченной субъективности и достижению иелостности «я» рассматривается как важное метафизическое свойство личности. Выделены некоторые социальнокультурные ограничения идеологии антропологического преобразования: семейственность, женственность, национальные традиции. Автор считает, что в современном запросе на трансиендирование выражается как критика окружающей действительности, глубокая неудовлетворенность настоящим и нежелание ограничиваться модификациями старого, так и поиск и освоение принциииально нового.
\end{abstract}

Ключевые слова: трансиендентное, гуманизм, постгуманизм, «неочеловек», трансиендирование, культурные ограничения, традиции.

Научная специальность: 09.00.00 - философские науки. 